\title{
Are racial differences in hospital mortality after coronary artery bypass graft surgery real? A risk-adjusted meta-analysis
}

\author{
Umberto Benedetto, MD, PhD, ${ }^{a}$ Mohamed K. Kamel, MD, ${ }^{b}$ Faiza M. Khan, MD, ${ }^{b}$ Gianni D. Angelini, MD, ${ }^{a}$ \\ Massimo Caputo, MD, ${ }^{\mathrm{a}}$ Leonard N. Girardi, MD, ${ }^{\mathrm{b}}$ and Mario Gaudino, $\mathrm{MD}^{\mathrm{b}}$
}

\section{ABSTRACT}

Background: Despite several reports, there are still conflicting data on the influence of ethnicity on mortality rates associated with coronary artery bypass grafting $(\mathrm{CABG})$. We aimed to get further insights into the effect of race on mortality following $\mathrm{CABG}$ by performing a risk adjusted meta-analysis.

Methods: Relevant studies were searched on PubMed, Embase, BioMed Central, and the Cochrane Central register. Pairwise meta-analysis was used to estimate the relative risk of hospital death of black, Hispanic, and Asian patients using white patients as reference. Risk adjusted meta-analytic estimates were obtained using generic inverse variance methods with random effect model.

Results: A total of 28 studies were selected for analysis. A total of 21 studies reported on hospital mortality in black $(n=222,892)$ versus white $(n=3,884,043)$ patients, 7 studies reported on Hispanic $(n=91,256)$ versus white $(n=1,458,524)$ and 9 studies reported on Asian $(n=27,820)$ versus white $(n=1,081,642)$. When compared with white patients, adjusted risk of hospital death was significantly greater for black patients (adjusted odds ratio [OR], 1.25; 95\% confidence interval $[\mathrm{CI}], 1.13-1.39 ; P<.001)$, and not statistically different for Asian (OR, 1.33; 95\% CI, 0.99-1.77; $P=.05$ ) and Hispanic patients (adjusted OR, 1.08; 95\% CI, $0.94-1.23 ; P=.26)$. Meta-regression showed a significant trend toward lower mortality rates in most recent series in both black $(P=.02)$ and white $(P=.0007)$ and Asian $(P=.01)$ but not for Hispanic $(P=.41)$. However, as mortality rates were lower across the different races, the relative disadvantage between the study groups persisted, which may explain the lack of interaction between study period and race effect on mortality for black (adjusted $P=.09$ ),

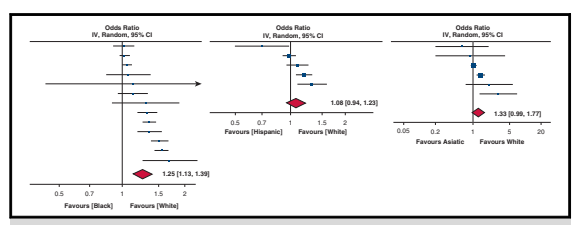

Meta-analytic risk-adjusted estimates of race effect on operative mortality.

\section{Central Message}

Despite progress being made in lowering inhospital mortality rates among the major racial/ethnic groups, ethnic disparities in hospital mortality after coronary bypass surgery remain.

\section{Prospective}

The effect of race on mortality after coronary bypass surgery remains uncertain, and current guidelines and risk stratification systems make no differentiation by race. We showed that despite progress being made in lowering in-hospital mortality rates among the major racial/ethnic groups, ethnic disparities in hospital mortality after CABG remain.

See Commentary on page 2226. Asian (adjusted $P=.63$ ), and Hispanic (adjusted $P=.97$ ) patients.

Conclusions: The present meta-analysis showed that despite progress is being made in lowering in-hospital mortality rates among the major racial/ethnic groups, ethnical disparities in hospital mortality after CABG remain. (J Thorac Cardiovasc Surg 2019;157:2216-25)

Although multiple studies have found that non-white patients, in particular black and Hispanic, have lower rates

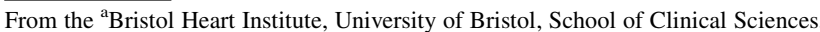
Bristol, United Kingdom; and ${ }^{\mathrm{b}}$ Department of Cardiothoracic Surgery, Weill Cornell Medicine, New York, NY.

Supported by the NIHR Bristol Biomedical Research Centre Cardiovascular Theme. Drs Benedetto and Kamel contributed equally to this manuscript.

Received for publication Sept 12, 2017; revisions received Nov 12, 2018; accepted for publication Dec 2, 2018; available ahead of print Jan 30, 2019.

Address for reprints: Umberto Benedetto, $\mathrm{MD}, \mathrm{PhD}$, Bristol Heart Institute, University of Bristol, Upper Maudlin St, Bristol BS2 8HW United Kingdom (E-mail: umberto.benedetto@bristol.ac.uk).

$0022-5223 / \$ 36.00$

Copyright (c) 2018 by The American Association for Thoracic Surgery https://doi.org/10.1016/j.jtcvs.2018.12.002
}

of cardiovascular procedures, including cardiac catheterization, percutaneous coronary intervention, and coronary artery bypass grafting $(\mathrm{CABG}),{ }^{1}$ there are still limited and conflicting data on the influence of ethnicity on mortality and complication rates associated with $\mathrm{CABG}^{2-6}$ One

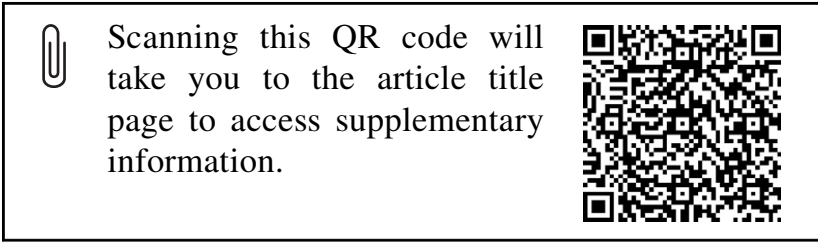




\section{Abbreviations and Acronyms \\ $\mathrm{CABG}=$ coronary artery bypass grafting \\ $\mathrm{CI}=$ confidence interval \\ $\mathrm{OR} \quad=$ odds ratio}

potential concern is that if racial minorities are less likely to be referred for cardiac catheterization and coronary revascularization, then only those with particularly advanced disease or compelling indications may undergo these procedures, leading to worse outcomes. ${ }^{2-4}$ Previous studies evaluating the impact of ethnicity on mortality following $\mathrm{CABG}$ surgery have had mixed conclusions. Several studies have reported greater mortality for black patients following the operation. ${ }^{5,6}$ Other studies have suggested similar risk-adjusted survival for black patients following CABG surgery. ${ }^{2-4}$ Therefore, the effect of race on mortality after CABG remains uncertain, ${ }^{2}$ and current CABG guidelines $^{7}$ and risk-stratification systems ${ }^{8,9}$ make no differentiation by race. We aimed to get further insights into the effect of race on mortality following CABG by performing a risk-adjusted meta-analysis of comparative studies.

\section{METHODS}

\section{Literature Search Strategy}

The search strategy adopted is in accordance with the Meta-analysis of Observational Studies in Epidemiology guidelines. ${ }^{10}$ We searched PubMed, the Cochrane Central Register of Controlled Trials, and
EMBASE from their inception to March 2017, without language restrictions. Search algorithm used was "race" OR "ethnicity" AND ("coronary artery bypass" OR CABG OR "bypass surgery" OR "coronary bypass"). In addition, reference lists of the identified reports and relevant reviews were manually screened by 2 reviewers (U.B., M.K.) to identify relevant studies. Studies reporting hospital outcomes after CABG across different ethnic groups including white, black, Hispanic, and Asian patients were selected. When centers have published duplicate trials with accumulating numbers of patients, only the largest reports were included for qualitative appraisal (Online Data Supplement). Non-English articles were not excluded. Abstracts, case reports, conference presentations, editorials, and expert opinions were excluded. Disagreements were resolved by consensus. The quality of included studies was assessed with the Newcastle-Ottawa scale for observational studies. ${ }^{11}$ The total score was 9 stars, and the quality was graded as low level ( $<6$ stars) or high level ( $\geq 6$ stars). Baseline characteristics and hospital outcomes in different ethnic groups were independently abstracted by 2 investigators (U.B., M.K.). The primary outcome of the present meta-analysis was hospital mortality. Hospital mortality crude incidence rates for different ethnic groups were obtained from individual studies. As different ethnic groups can present different patient-level and hospital-level factors distribution, we also extracted fully adjusted estimates obtained by multivariate models from individual studies. Other operative outcomes investigated were stroke, wound infection, renal failure/dialysis, re-exploration for bleeding, and respiratory failure/tracheostomy.

\section{Statistical Analysis}

Pairwise meta-analysis methods were used to estimate operative mortality relative risk for different ethnic groups (black, Hispanic, and Asian) using the white group as reference. A subgroup analysis was done to compare South Asian with white. Individual study and pooled operative mortality were reported as odds ratio (OR) with a $95 \%$ confidence interval (CI). Unadjusted pooled estimates were obtained using the model of DerSimonian and Laird. ${ }^{12}$ Individual studies risk-adjusted estimates were pooled as log OR and standard error using the generic inverse variance method. ${ }^{13}$

\section{IDENTIFICATION}

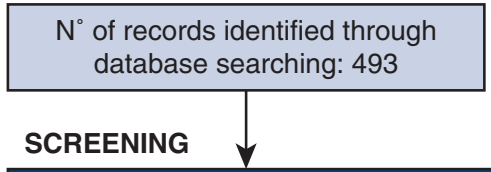

$\mathrm{N}^{\circ}$ of records identified through other sources: 869

$\mathrm{N}^{\circ}$ of records identified on the basis of title/abstract/language/duplicates removal: 150

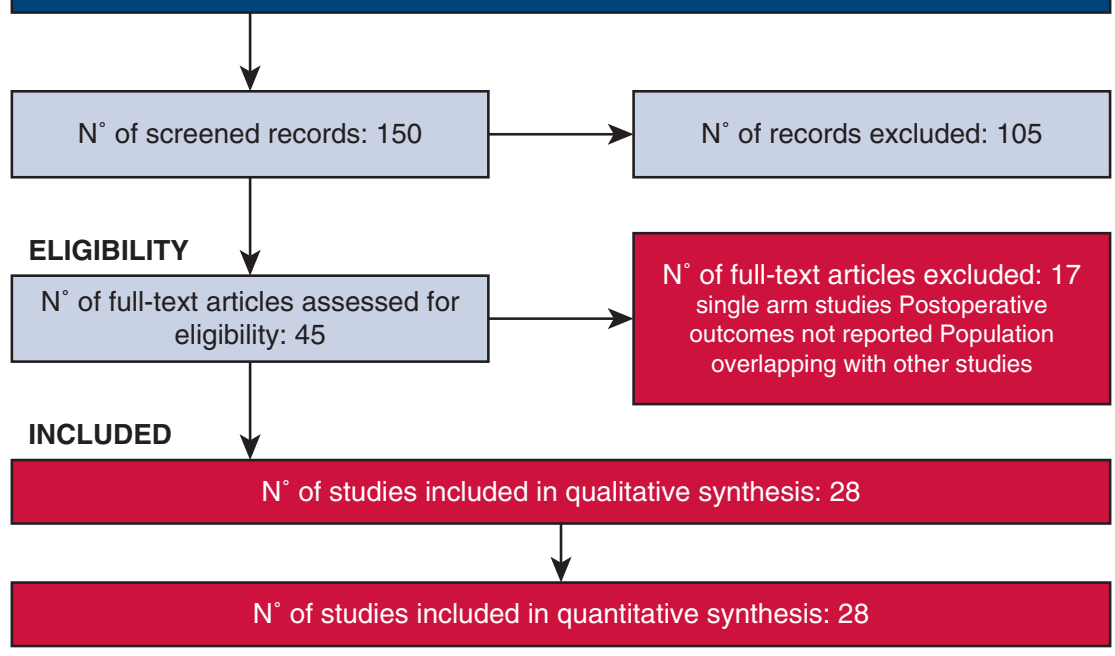

FIGURE 1. Study selection process for meta-analysis. 
TABLE 1. Overview of studies included in the meta-analysis

\begin{tabular}{|c|c|c|c|c|c|c|c|c|c|c|}
\hline $\begin{array}{l}\mathrm{N} \text { of } \\
\text { study }\end{array}$ & $\begin{array}{c}\text { First author and } \\
\text { year of } \\
\text { publication }\end{array}$ & Country & $\begin{array}{c}\text { Single vs } \\
\text { multi-institution }\end{array}$ & $\begin{array}{c}\text { Years of } \\
\text { enrollment }\end{array}$ & $\begin{array}{c}\text { Information on } \\
\text { source of data }\end{array}$ & $\begin{array}{c}\text { White } \\
\text { patients (N) }\end{array}$ & $\begin{array}{c}\text { Black } \\
\text { patients (N) }\end{array}$ & $\begin{array}{c}\text { Asian } \\
\text { patients (N) }\end{array}$ & $\begin{array}{c}\text { Hispanic } \\
\text { Patients (N) }\end{array}$ & $\begin{array}{c}\text { Race } \\
\text { identification }\end{array}$ \\
\hline 1 & $\begin{array}{l}\text { Anderson } \\
\text { et al, },^{31} 2016\end{array}$ & US & Multi-institution & 2011-2012 & $\begin{array}{l}\text { California CABG } \\
\text { Reporting Program }\end{array}$ & 14,389 & 975 & 3196 & 4614 & $*$ \\
\hline 2 & $\begin{array}{l}\text { Andrews } \\
\text { et al },{ }^{34} 2015\end{array}$ & US & Multi-institution & 2009 & $\begin{array}{l}\text { Healthcare Research } \\
\text { and Quality (NIS) }\end{array}$ & 194,440 & 15,534 & & & * \\
\hline 3 & $\begin{array}{l}\text { Becker and } \\
\quad \text { Rahimi, }{ }^{6} 2006\end{array}$ & US & Multi-institution & 1993-2002 & $\begin{array}{r}\text { Healthcare Research } \\
\text { and Quality (NIS) }\end{array}$ & $1,040,641$ & 63,991 & 20,353 & 67,554 & * \\
\hline 4 & $\begin{array}{l}\text { Bridges } \\
\text { et al, }{ }^{5} 2000\end{array}$ & US & Multi-institution & 1994-1997 & $\begin{array}{l}\text { Society of Thoracic } \\
\text { Surgeons (STS) }\end{array}$ & 555,939 & 25,850 & & & Self-identified \\
\hline 5 & $\begin{array}{l}\text { Brister } \\
\text { et al, }{ }^{22} 2007\end{array}$ & Canada & Single institution & $1994-2003$ & - & 917 & & 917 & & $\begin{array}{r}\text { Self-identified \& } \\
\text { patients' name }\end{array}$ \\
\hline 6 & $\begin{array}{l}\text { Chowdhury } \\
\text { et al, }{ }^{33} 2017\end{array}$ & US & Single institution & 2006-2010 & - & 3107 & 389 & & & Self-identified \\
\hline 7 & $\begin{array}{l}\text { Cooper } \\
\text { et al, }{ }^{28} 2009\end{array}$ & US & Multi-institution & 1997-2007 & $\begin{array}{l}\text { Society of Thoracic } \\
\text { Surgeons (STS) }\end{array}$ & 10,841 & 2033 & & & $*$ \\
\hline 8 & $\begin{array}{l}\text { Efird } \\
\text { et al, }{ }^{16} 2015\end{array}$ & US & Single institution & $1992-2011$ & - & 11,395 & 2379 & & & Self-identified \\
\hline 9 & $\begin{array}{l}\text { Gasevic } \\
\text { et al, }{ }^{20} 2013\end{array}$ & Canada & Multi-institution & 1999-2003 & $\begin{array}{l}\text { British Columbia } \\
\quad \text { Cardiac Registry }\end{array}$ & 1507 & & 180 & & Patients' name \\
\hline 10 & $\begin{array}{l}\text { Goldsmith } \\
\text { et al, }{ }^{37} 1999\end{array}$ & UK & Single institution & 1994-1997 & - & 190 & & 194 & & $*$ \\
\hline 11 & Gray et al, ${ }^{25} 1996$ & US & Single institution & 1984-1992 & - & 3113 & 115 & & & $*$ \\
\hline 12 & $\begin{array}{l}\text { Hadjinikolaou } \\
\text { et al },^{36} 2010\end{array}$ & UK & Single institution & $2002-2007$ & - & 2623 & & 274 & & Self-identified \\
\hline 13 & Kaila et al, ${ }^{18} 2014$ & Canada & Multi-institution & 1999-2012 & $\begin{array}{l}\text { APPROACH } \\
\text { database }\end{array}$ & 737 & & 252 & & Patients' name \\
\hline 14 & $\begin{array}{l}\text { Keeling } \\
\text { et al, }{ }^{32} 2017\end{array}$ & US & Single institution & $2002-2014$ & - & 13,569 & 2810 & & & $*$ \\
\hline 15 & $\begin{array}{l}\text { Kim } \\
\text { et al, }{ }^{21} 2008\end{array}$ & US & Multi-institution & 2002-2005 & $\begin{array}{l}\text { University } \\
\text { HealthSystem } \\
\text { Consortium }\end{array}$ & 63,487 & 8462 & & & $*$ \\
\hline 16 & $\begin{array}{l}\text { Konety } \\
\text { et al, }{ }^{23} 2005\end{array}$ & US & Multi-institution & 1997-2000 & $\begin{array}{l}\text { Medicare Provider } \\
\text { and Analysis } \\
\text { Review }\end{array}$ & 566,785 & 24,354 & & & * \\
\hline 17 & $\begin{array}{l}\text { Lucas } \\
\quad \text { et al, }{ }^{35} 2006\end{array}$ & US/Canada & Multi-institution & 1994-1999 & $\begin{array}{l}\text { Medicare Provider } \\
\text { and Analysis } \\
\text { Review }\end{array}$ & 829,037 & 33,367 & & & * \\
\hline 18 & $\begin{array}{l}\text { Maynard and } \\
\text { Ritchie, }{ }^{24} 2001\end{array}$ & US & Multi-institution & 1994-1999 & Veterans Affairs & 27,439 & 2380 & & & $*$ \\
\hline 19 & $\begin{array}{l}\text { Mehta } \\
\quad \text { et al, }{ }^{30} 2016\end{array}$ & US & Multi-institution & 2010-2011 & $\begin{array}{l}\text { Society of } \\
\text { Thoracic } \\
\text { Surgeons (STS) }\end{array}$ & 136,362 & 14,375 & & & * \\
\hline 20 & $\begin{array}{l}\text { O'Neal } \\
\quad \text { et al, }{ }^{29} 2014\end{array}$ & US & Single institution & $2002-2011$ & - & 3460 & 970 & & & Self-identified \\
\hline 21 & $\begin{array}{l}\text { Pollock } \\
\text { et al, }{ }^{17} 2015\end{array}$ & US & Single institution & 2004-2011 & - & 6365 & 612 & & 593 & $*$ \\
\hline 22 & $\begin{array}{l}\text { Rangrass } \\
\text { et al },{ }^{19} 2014\end{array}$ & US & Multi-institution & 2007-2008 & $\begin{array}{l}\text { Medicare Analysis } \\
\text { Provider and } \\
\text { Review }\end{array}$ & 159,043 & 9390 & & 3016 & $*$ \\
\hline 23 & $\begin{array}{l}\text { Rumsfeld } \\
\text { et al, }{ }^{4} 2002\end{array}$ & US & Multi-institution & $1995-2001$ & Veterans Affairs & 29,333 & 2570 & & 1525 & * \\
\hline 24 & $\begin{array}{l}\text { Smith } \\
\text { et al, }{ }^{27} 2006\end{array}$ & US & Multi-institution & 1993-2005 & $\begin{array}{l}\text { Multi-institutional } \\
\text { database }\end{array}$ & 1932 & 644 & & & $*$ \\
\hline
\end{tabular}


TABLE 1. Continued

\begin{tabular}{|c|c|c|c|c|c|c|c|c|c|c|}
\hline $\begin{array}{l}\mathrm{N} \text { of } \\
\text { study }\end{array}$ & $\begin{array}{c}\text { First author and } \\
\text { year of } \\
\text { publication }\end{array}$ & Country & $\begin{array}{c}\text { Single vs } \\
\text { multi-institution }\end{array}$ & $\begin{array}{c}\text { Years of } \\
\text { enrollment }\end{array}$ & $\begin{array}{l}\text { Information on } \\
\text { source of data }\end{array}$ & $\begin{array}{c}\text { White } \\
\text { patients }(\mathbf{N})\end{array}$ & $\begin{array}{c}\text { Black } \\
\text { patients }(\mathbf{N})\end{array}$ & $\begin{array}{c}\text { Asian } \\
\text { patients }(\mathbf{N})\end{array}$ & $\begin{array}{c}\text { Hispanic } \\
\text { Patients (N) }\end{array}$ & $\begin{array}{c}\text { Race } \\
\text { identification }\end{array}$ \\
\hline 25 & $\begin{array}{l}\text { Trivedi } \\
\text { et al, }^{26} 2006\end{array}$ & US & Multi-institution & $1998-2001$ & $\begin{array}{l}\text { Healthcare Research } \\
\text { and Quality (NIS) }\end{array}$ & 193,684 & 11,393 & & 11,393 & $*$ \\
\hline 26 & $\begin{array}{l}\text { Yeo } \\
\text { et } \mathrm{al}^{3}{ }^{3} 2007\end{array}$ & US & Multi-institution & 2003 & $\begin{array}{l}\text { California CABG } \\
\text { Outcomes Reporting } \\
\text { Program }\end{array}$ & 15,069 & 785 & 1772 & 2561 & * \\
\hline 27 & $\begin{array}{l}\text { Zacharias } \\
\qquad \text { et } \mathrm{al}^{2}, 2005\end{array}$ & US & Single institution & $1991-2003$ & - & 6073 & 304 & & & $*$ \\
\hline 28 & $\begin{array}{l}\text { Zindrou } \\
\text { et al, }{ }^{38} 2001\end{array}$ & UK & Single institution & 1993-1997 & - & 1458 & & 436 & & Self-identified \\
\hline
\end{tabular}

$C A B G$, Coronary artery bypass graft; NIS, National Inpatient Sample. *As reported in single/multiple institutional or national databases.

Random effect was used in all meta-analyses to obtain more conservative estimates. ${ }^{14}$ We used the $\mathrm{I}^{2}$ statistic, which estimates the percentage of total variation across studies that is due to heterogeneity rather than chance. Suggested thresholds for heterogeneity were used, with $\mathrm{I}^{2}$ values of $25 \%$ to $49 \%, 50 \%$ to $74 \%$, and $\geq 75 \%$, indicative of low, moderate, and high heterogeneity. ${ }^{15,16}$ For each study, median year of enrollment was obtained and changes in estimates across different eras were tested using meta-regression model (mixed-effects model). Meta-analytic estimates were computed using Review Manager (RevMan, Computer program, Version 5.2; The Nordic Cochrane Centre, The Cochrane Collaboration, 2012, Copenhagen, Denmark) and meta $\mathrm{R}$ package ( $\mathrm{R}$ Core Team, 2016. R: A language and environment for statistical computing. R Foundation for Statistical Computing, Vienna, Austria; https://www.R-project.org/).

\section{RESULTS}

\section{Study Selection}

A total of 1362 references were identified through electronic database searches and references lists. After exclusion of duplicate or irrelevant references, 45 potentially relevant articles were retrieved. After detailed evaluation of these articles, 28 studies were selected for analysis. ${ }^{2-}$ 6,16-38 (Figure 1). Study overview, patients' characteristics, and severity of coronary artery disease are reported in Table 1, Table 2, and Table E1, respectively. A total of 21 studies reported on hospital mortality in black $(\mathrm{n}=222,892)$ versus white $(\mathrm{n}=3,884,043)$ patients, 7 studies reported on Hispanic $(\mathrm{n}=91,256)$ versus white $(\mathrm{n}=1,458,524)$ patients, and 9 studies reported on Asian $(\mathrm{n}=27,820)$ versus white $(\mathrm{n}=1,081,642)$ patients. Of the 9 studies that reported on Asian patients, 5 studies reported on South Asians, 1 study reported on South Asians and Chinese, and 3 studies did not distinguish between the different Asian ethnicities. Fully adjusted estimates including patient-level and hospital-level covariates were reported by 12 studies for black versus white comparison, 4 studies for Hispanic versus white comparison, and 4 studies for Asian versus white comparison. The methods and variables used in adjustment are listed in Table E2. Quality assessment of individual studies is reported in Table 3.

\section{Meta-Analysis}

Meta-analysis of unadjusted rates (Figure 2) showed that when compared with white patients, black (unadjusted OR, $1.24 ; 95 \% \mathrm{CI}, 1.20-1.28 ; P<.001$ ) and Asian patients (unadjusted OR, 1.33 ; 95\% CI, 1.05-1.69; $P=.02$ ) were associated with a significantly increased risk for hospital death whereas Hispanic patients presented a comparable risk (unadjusted OR, 0.98; 95\% CI, 0.87-1.09; $P=.66$ ). This trend was confirmed when reported adjusted estimates for hospital mortality were pooled (Figure 3 ). When compared with white patients, adjusted risk of hospital death was significantly greater for black patients (adjusted OR, 1.25; 95\% CI, 1.13-1.39; $P<.001$ ), and not statistically different for Asian (OR, 1.33; 95\% CI, 0.99, 1.77; $P=.05)$ and Hispanic patients (adjusted OR, 1.08; 95\% CI, 0.94-1.23; $P=.26$ ).

A subgroup analysis showed that South Asian patients had greater risk of crude hospital mortality compared with white patients (unadjusted OR, 1.72; 95\% CI, 1.12-2.66; $P=.01)$. However, there was no difference in the risk of hospital mortality between South Asian and white patients after adjusting for possible confounding factors (adjusted OR, 1.73; 95\% CI, 0.71-4.18; $P=.23$ ) (Figure E1).

Meta-regression (Figure 4) showed a significant trend toward lower mortality rates in most recent series in both black $(P=.02)$ and white $(P=.0007)$ and Asian $(P=.01)$ patients but not for Hispanic patients $(P=.41)$. However, as mortality rates were lower across the different races, the relative disadvantage between the study groups persisted, which may explain the lack of interaction between study period and race effect on mortality for black (unadjusted $P=.29$, adjusted $P=.09$ ), Asian (unadjusted $P=.15$, adjusted $P=.63$ ), and Hispanic (unadjusted and adjusted $P=.97$ ) patients.

\section{Postoperative Complications}

For the comparison between black and white patients, several studies reported also on unadjusted rate of postoperative complication (Figure E2). Pooled estimates showed 
TABLE 2. Patients' characteristics in studies included in the meta-analysis

\begin{tabular}{|c|c|c|c|c|c|c|c|c|c|c|c|c|}
\hline \multirow[b]{2}{*}{ Study } & \multicolumn{4}{|c|}{ Mean age, $y$} & \multicolumn{4}{|c|}{$\%$ Female } & \multicolumn{4}{|c|}{$\%$ Diabetes mellitus } \\
\hline & White & Black & Asian & Hispanic & White & Black & Asian & Hispanic & White & Black & Asian & $\overline{\text { Hispanic }}$ \\
\hline \multicolumn{13}{|l|}{ Anderson et al, ${ }^{31} 2016$} \\
\hline Andrews et al,${ }^{34} 2015$ & & & & & $27.10 \%$ & $42.60 \%$ & & & & & & \\
\hline $\begin{array}{l}\text { Becker and } \\
\text { Rahimi, }^{6} 2006\end{array}$ & & & & & $28.40 \%$ & $44 \%$ & $27.70 \%$ & $31.40 \%$ & & & & \\
\hline Bridges et al, 2000 & 65 & 62 & & & $27.93 \%$ & $44.45 \%$ & & & $27.82 \%$ & $43.78 \%$ & & \\
\hline Brister et al, ${ }^{22} 2007$ & 62 & & 61 & & $23.50 \%$ & & $23.60 \%$ & & $37.30 \%$ & & $39.40 \%$ & \\
\hline $\begin{array}{l}\text { Chowdhury } \\
\text { et al, }{ }^{33} 2017\end{array}$ & 58 & 56 & & & $10 \%$ & $21 \%$ & & & & & & \\
\hline Cooper et al, ${ }^{28} 2009$ & 63 & 60 & & & $27 \%$ & $42 \%$ & & & $33.60 \%$ & $47.00 \%$ & & \\
\hline Efird et al, ${ }^{16} 2015$ & 65 & 62 & & & $27.30 \%$ & $42 \%$ & & & $32.00 \%$ & $48.00 \%$ & & \\
\hline Gasevic et al, ${ }^{20} 2013$ & & & & & $21 \%$ & & $18 \%$ & & $21.30 \%$ & & $31.00 \%$ & \\
\hline Goldsmith et al, ${ }^{37} 1999$ & 58 & & 58 & & & & & & $11.60 \%$ & & $38.70 \%$ & \\
\hline Gray et $a 1,{ }^{25} 1996$ & 67 & 65 & & & $21 \%$ & $35 \%$ & & & $23.00 \%$ & $36.00 \%$ & & \\
\hline $\begin{array}{l}\text { Hadjinikolaou } \\
\text { et al },^{36} 2010\end{array}$ & 66 & & 63 & & $19.70 \%$ & & $23 \%$ & & & & & \\
\hline Kaila et al, ${ }^{18} 2014$ & & & & & $20.30 \%$ & & $21.40 \%$ & & $47.80 \%$ & & $44.40 \%$ & \\
\hline Keeling et al, ${ }^{32} 2017$ & 64 & 61 & & & & & & & $37.10 \%$ & $50.30 \%$ & & \\
\hline \multicolumn{13}{|l|}{ Kim et al, ${ }^{21} 2008$} \\
\hline Konety et al, ${ }^{23} 2005$ & 74 & 72 & & & $34.40 \%$ & $51.40 \%$ & & & $8.30 \%$ & $18.40 \%$ & & \\
\hline Lucas et $\mathrm{al}^{35} 2006$ & & & & & $34.30 \%$ & $51.50 \%$ & & & & & & \\
\hline $\begin{array}{l}\text { Maynard and } \\
\text { Ritchie, }{ }^{24} 2001\end{array}$ & 64 & 63 & & & $1 \%$ & $1 \%$ & & & $30.00 \%$ & $34.00 \%$ & & \\
\hline Mehta et al, ${ }^{30} 2016$ & 66 & 62 & & & $25.30 \%$ & $40.40 \%$ & & & $39.10 \%$ & $53.00 \%$ & & \\
\hline O'Neal et al, ${ }^{29} 2014$ & 64 & 61 & & & $25 \%$ & $38 \%$ & & & $37.20 \%$ & $50.00 \%$ & & \\
\hline Pollock et al, ${ }^{17} 2015$ & 65 & 62 & & 61 & $23.70 \%$ & $44 \%$ & & $27.50 \%$ & $37.10 \%$ & $46.60 \%$ & & $61.20 \%$ \\
\hline Rangrass et al, ${ }^{19} 2014$ & 74 & & & & $30.50 \%$ & & & & $29.30 \%$ & & & \\
\hline Rumsfeld et al, ${ }^{4} 2002$ & 63.6 & 62.2 & & 63.8 & $1.10 \%$ & $1.10 \%$ & & $0.50 \%$ & $31.40 \%$ & $38.10 \%$ & & $47.80 \%$ \\
\hline Smith et al, ${ }^{27} 2006$ & 64.6 & 63.7 & & & $28.60 \%$ & $45.70 \%$ & & & $30.40 \%$ & $47.20 \%$ & & \\
\hline \multicolumn{13}{|l|}{ Trivedi et al, ${ }^{26} 2006$} \\
\hline Yeo et al, ${ }^{3} 2007$ & 66.91 & 63.17 & 65.6 & 64.02 & $25 \%$ & $43 \%$ & $27 \%$ & $31 \%$ & $33.00 \%$ & $49.00 \%$ & $47.00 \%$ & $56 \%$ \\
\hline Zacharias et al, ${ }^{2} 2005$ & 64 & 62 & & & $29.80 \%$ & $46.10 \%$ & & & $32.40 \%$ & $43.40 \%$ & & \\
\hline Zindrou et $\mathrm{al}^{38}{ }^{38} 2001$ & 61.6 & & 59.6 & & $15.98 \%$ & & $19.70 \%$ & & $17.50 \%$ & & $43.00 \%$ & \\
\hline
\end{tabular}

that rate for stroke (unadjusted OR, 1.78; 95\% CI, 1.492.13; $P<.001$ ), bleeding (unadjusted OR, 1.24; 95\% CI, 1.09-1.41), tracheostomy/reintubation (unadjusted OR, 1.37; 95\% CI, 1.15-1.61; $P=.0003$ ), and renal failure (adjusted OR, 1.54; 95\% CI, 1.38-1.73; $P<.001$ ) but not wound infection (OR, 1.16; 95\% CI, 0.98-1.36; $P=.09$ ) were greater among black patients.

\section{DISCUSSION}

In the present study, we investigated the effect of race by performing a meta-analysis and meta-regression of comparative studies available. We showed that black race was associated with increased mortality rates when compared with white race also after adjusting for patient-level and hospital-level factors. We also showed that despite the fact that mortality rates declined over the years for black patients, a specular reduction in mortality was observed for white patients. Therefore, the gap between black and white patients remained stable. Black race was also shown to be associated with significant increased risk of postoperative complications, including bleeding, stroke, renal failure/ dialysis, and respiratory failure/tracheostomy. Although not statistically significant, there was a strong trend toward an increased risk of mortality in Asian when compared with white subjects $(P=.05)$. In contrast, Hispanic patients were consistently found to have mortality rates comparable with those observed in white patients without significant changes across different eras. 
TABLE 3. Study quality assessment using Newcastle Ottawa Scale

\begin{tabular}{|c|c|c|c|c|}
\hline Study & Selection & Comparability & Exposure & Sum \\
\hline Anderson et al,${ }^{31} 2016$ & 4 & 2 & 3 & 9 \\
\hline Andrews et al, ${ }^{34} 2015$ & 4 & 2 & 3 & 9 \\
\hline $\begin{array}{l}\text { Becker and } \\
\text { Rahimi, }^{6} 2006\end{array}$ & 4 & 0 & 3 & 7 \\
\hline Bridges et al, ${ }^{5} 2000$ & 4 & 0 & 3 & 7 \\
\hline Brister et al, 22007 & 4 & 2 & 3 & 9 \\
\hline Chowdhury et al, ${ }^{33} 2017$ & 4 & 0 & 3 & 7 \\
\hline Cooper et al, ${ }^{28} 2009$ & 4 & 2 & 3 & 9 \\
\hline Efird et al, ${ }^{16} 2015$ & 4 & 0 & 3 & 7 \\
\hline Gasevic et al, ${ }^{20} 2013$ & 4 & 0 & 3 & 7 \\
\hline Goldsmith et al, ${ }^{37} 1999$ & 4 & 0 & 3 & 7 \\
\hline Gray et al, ${ }^{25} 1996$ & 4 & 2 & 3 & 9 \\
\hline $\begin{array}{l}\text { Hadjinikolaou } \\
\text { et al, }{ }^{36} 2010\end{array}$ & 4 & 0 & 3 & 7 \\
\hline Kaila et al, ${ }^{18} 2014$ & 4 & 2 & 3 & 9 \\
\hline Keeling et al, ${ }^{32} 2017$ & 4 & 2 & 3 & 9 \\
\hline Kim et al, ${ }^{21} 2008$ & 4 & 2 & 3 & 9 \\
\hline Konety et al,,$^{23} 2005$ & 4 & 2 & 3 & 9 \\
\hline Lucas et al, ${ }^{35} 2006$ & 4 & 2 & 3 & 9 \\
\hline $\begin{array}{l}\text { Maynard and } \\
\text { Ritchie, }{ }^{24} 2001\end{array}$ & 4 & 2 & 3 & 9 \\
\hline Mehta et al, ${ }^{30} 2016$ & 4 & 2 & 3 & 9 \\
\hline O'Neal et al, ${ }^{29} 2014$ & 4 & 0 & 3 & 7 \\
\hline Pollock et al, ${ }^{17} 2015$ & 4 & 0 & 3 & 7 \\
\hline Rangrass et al, ${ }^{19} 2014$ & 4 & 2 & 3 & 9 \\
\hline Rumsfeld et al, ${ }^{4} 2002$ & 4 & 2 & 3 & 9 \\
\hline Smith et al, ${ }^{27} 2006$ & 4 & 0 & 3 & 7 \\
\hline Trivedi et al, ${ }^{26} 2006$ & 4 & 2 & 3 & 9 \\
\hline Yeo et al, ${ }^{3} 2007$ & 4 & 0 & 3 & 7 \\
\hline Zacharias et $\mathrm{al}^{2}{ }^{2} 2005$ & 4 & 2 & 3 & 9 \\
\hline Zindrou et al,,$^{38} 2001$ & 4 & 0 & 3 & 7 \\
\hline
\end{tabular}

Despite several studies that have suggested ethnic disparities in operative outcomes following $\mathrm{CABG},{ }^{5,6}$ final conclusions are still lacking, and current CABG guidelines and risk stratification systems including the Society of Thoracic Surgeons scoring system (http:// riskcalc.sts.org/stswebriskcalc/) ${ }^{8}$ and the European System for Cardiac Operative Risk Evaluation (http://www. euroscore.org/) 9 make no differentiation by race in terms of operative mortality. The present study consistently demonstrated that black patients remain associated with a greater operative mortality, although this disparity was found to be relevant only among male patients.

There are a number of possible explanations for these persistent differences in outcomes between the different racial groups. First, it is well documented that disparities in access to health care system persist by race and black patients are likely to be referred to surgery with poorer health conditions. ${ }^{39,40}$ Although the present National Inpatient Sample analysis and meta-analysis controlled for many more patient, organizational, and socioeconomic aspects of CABG patients' condition, there still may be other unmeasured social phenomena of the patient's background, health condition, or hospital stay that may help explain racial/ethnic differences. In addition, many aspects of the physician-patient relationship that involve patients' education, trust, and the physician's sensitivity to a patient's culture might also play a critical role. ${ }^{40}$ Finally, others have identified genetic differences in race/ethnicity that could account for differences in outcomes. For patients with heart disease, some studies have suggested subtle differences among race/ethnicities in the biology of hypertension. Potential differences in the biology of hypertension may result in more frequent and more severe hypertension and ventricular hypertrophy in black patients. ${ }^{4}$

The present meta-analysis presents several limitations. The vast majority of the included studies did not mention the definitions used for race identification, a factor that may have influenced the results. Although we performed a risk-adjusted analysis, we cannot exclude the presence of residual confounding factors accounting for differences in outcomes between ethnic groups, which may have not been considered by individual studies. In particular, data on predicted risk of mortality (ie, SYNTAX score) were not provided in most of the studies. Moreover, detailed information on patients' socioeconomic status and surgeon and hospital volume were limited. The study focused primarily on operative mortality and did not compare the differences in long-term outcomes between the different race groups. Most of the series included in the present analysis were from US databases, and this might partially limit the generalizability of the present findings. In addition, despite we attempt to avoid cohort overlapping among different studies, we cannot exclude that different US nationwide databases might have reported on similar study populations. Finally, we acknowledge the difficulties and uncertainties that may sometimes be associated with defining individual patients' ethnicities, particularly for those residing in North America, where the population diversity may lead to racial mixing.

In conclusion, the present meta-analysis confirmed that despite progress is being made in lowering in-hospital mortality rates among the major racial/ethnic groups including black patients, significant disparities in outcomes still remain that warrant further investigation.

\section{Conflict of Interest Statement}

Authors have nothing to disclose with regard to commercial support. 


\section{Black vs white}

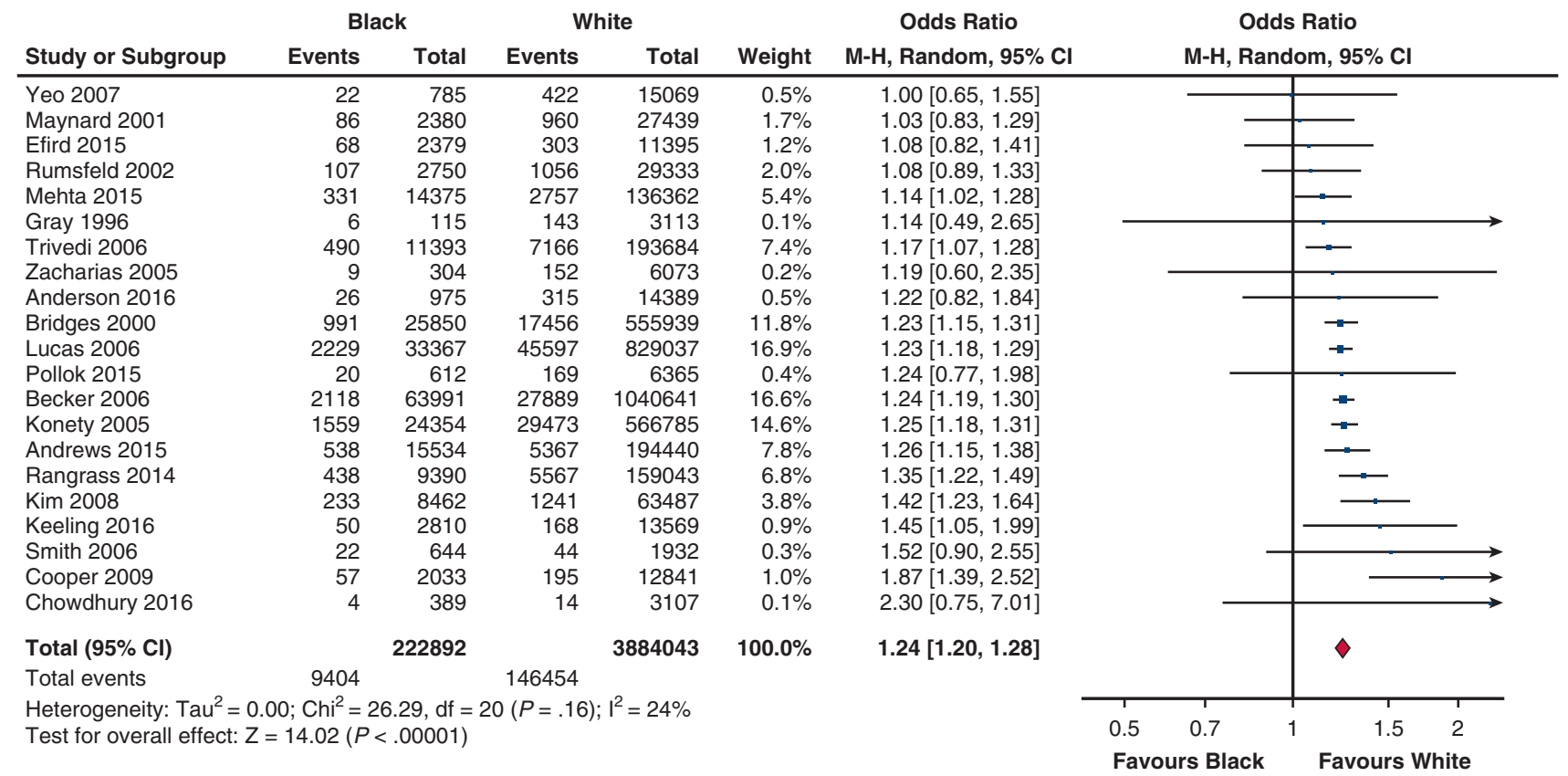

\section{A}

Hispanic vs white

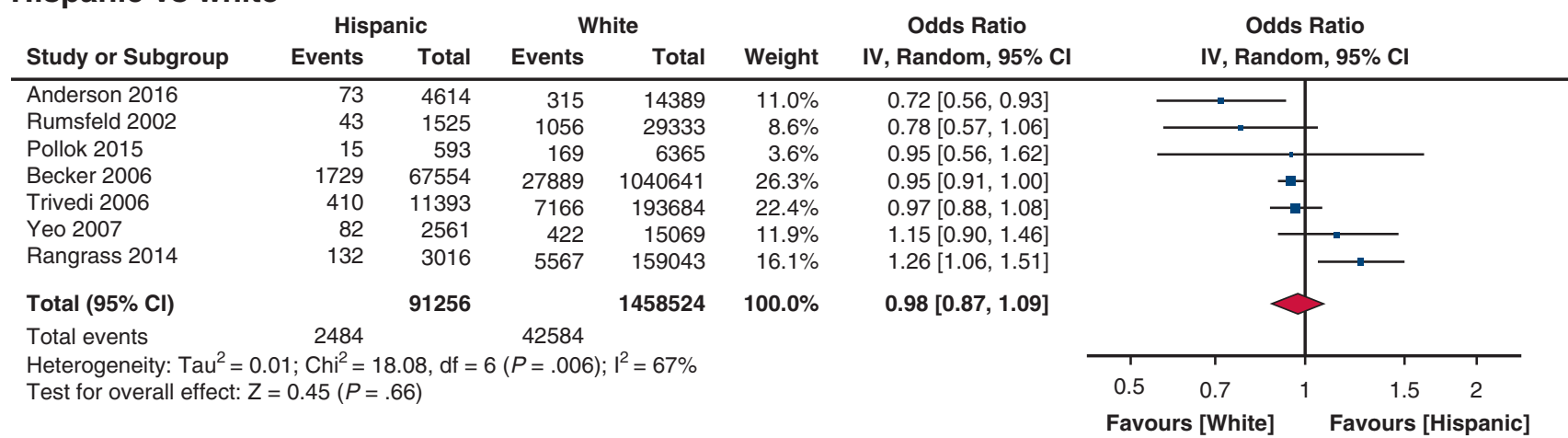

B

\section{Asiatic vs white}

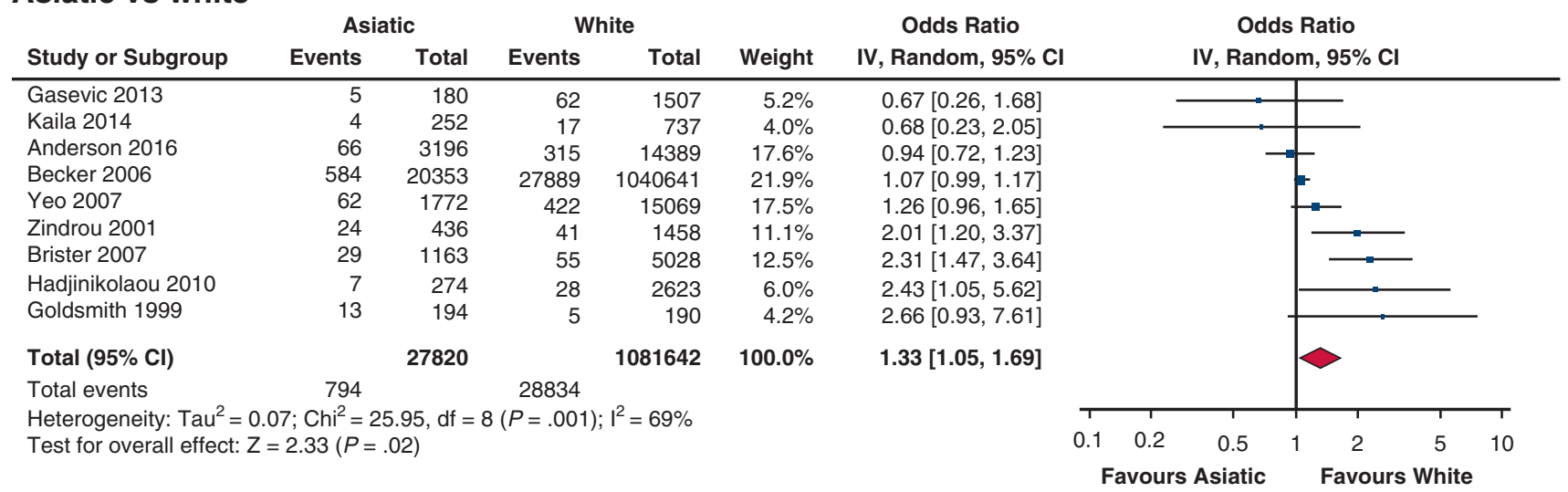

C

FIGURE 2. Meta-analytic unadjusted estimates of race effect on operative mortality (white as reference). $M$ - $H$, Mantel-Haenszel; $C I$, confidence interval; $I V$, inverse variance. 


\section{Black vs white}

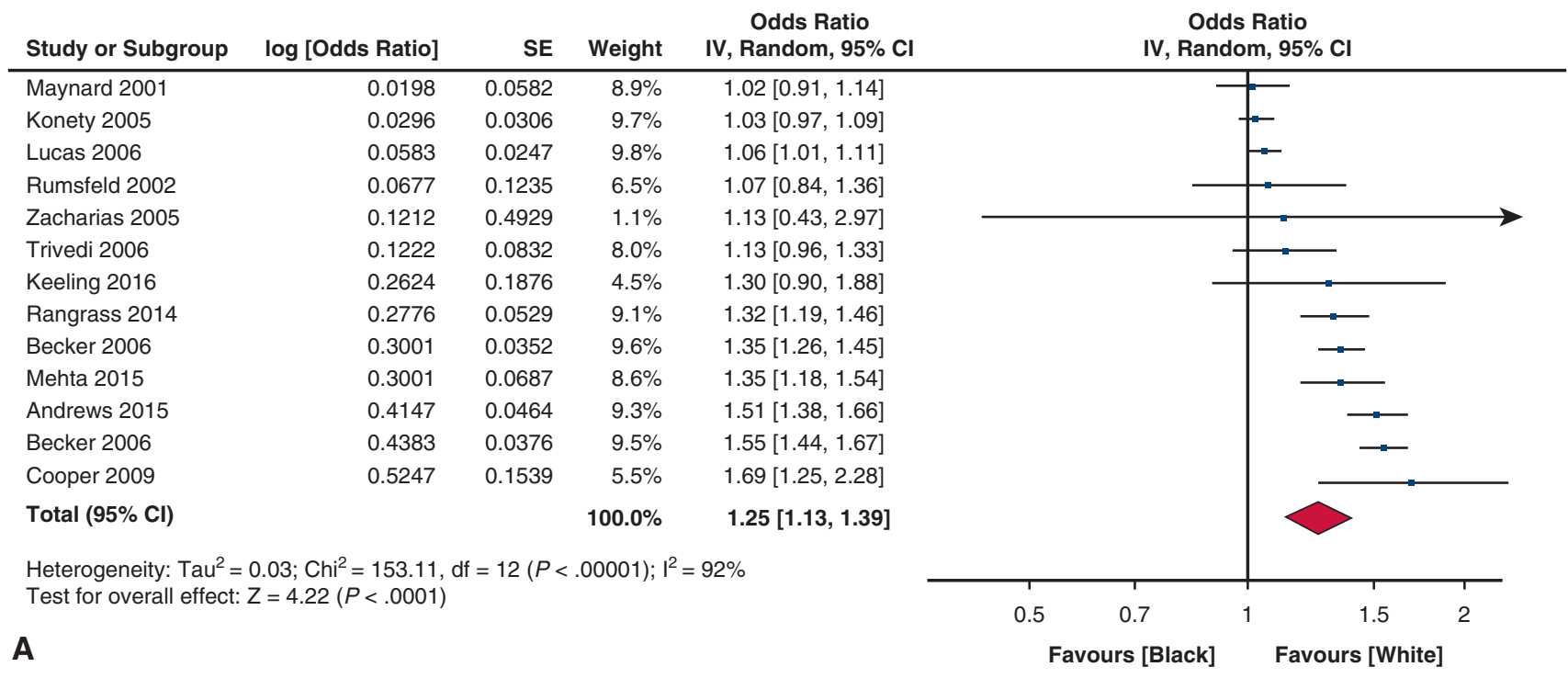

\section{Hispanic vs white}

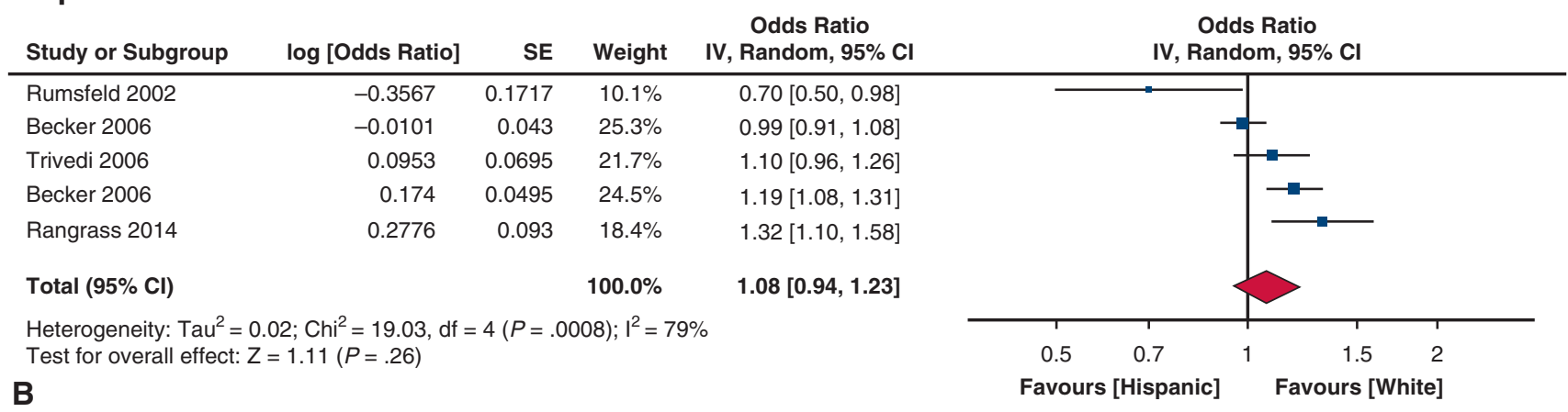

\section{Asiatic vs white}

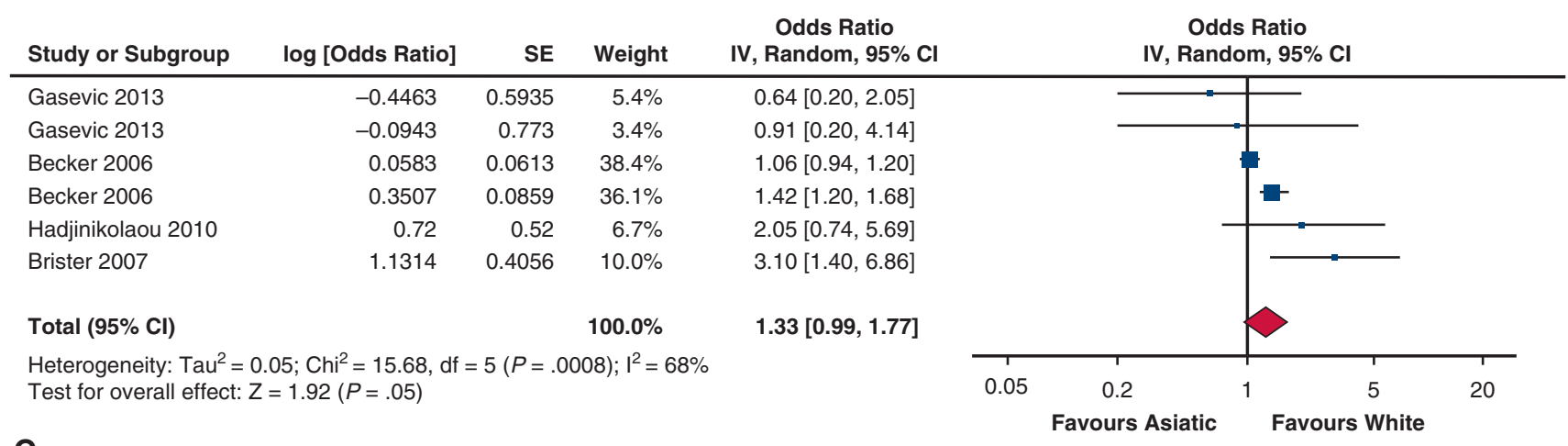

C

FIGURE 3. Meta-analytic risk-adjusted estimates of race effect on operative mortality (white as reference). $S E$, Standard error; $I V$, inverse variance; $C I$, confidence interval. 


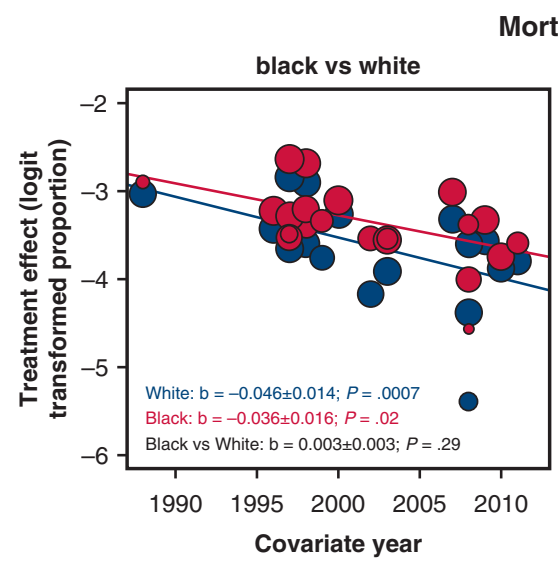

Mortality rates $(\log )$ in individual studies across different period
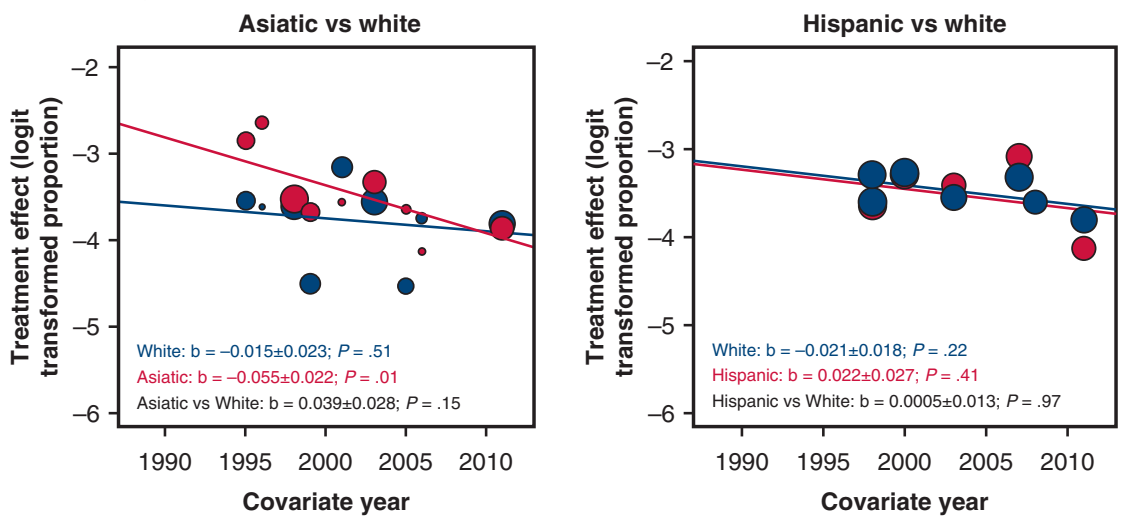

FIGURE 4. Meta-regression of crude mortality rate in separate ethnical groups and race effect on mortality across different study periods (median year of enrollment).

\section{References}

1. Peterson ED, Shaw LK, DeLong ER, Pryor DB, Califf RM, Mark DB. Racial variation in the use of coronary revascularization procedures. Are the differences real? Do they matter? N Engl J Med. 1997;336:480-6.

2. Zacharias A, Schwann TA, Riordan CJ, Durham SJ, Shah A, Habib RH Operative and late coronary artery bypass grafting outcomes in matched African-American versus Caucasian patients: evidence of a late survivalMedicaid association. J Am Coll Cardiol. 2005;46:1526-35.

3. Yeo KK, Li Z, Amsterdam E. Clinical characteristics and 30-day mortality among Caucasians, Hispanics, Asians, and African-Americans in the $2003 \mathrm{Cal}-$ ifornia coronary artery bypass graft surgery outcomes reporting program. Am J Cardiol. 2007;100:59-63.

4. Rumsfeld JS, Plomondon ME, Peterson ED, Shlipak MG, Maynard C, Grunwald GK, et al. The impact of ethnicity on outcomes following coronary artery bypass graft surgery in the Veterans Health Administration. J Am Coll Cardiol. 2002;40:1786-93.

5. Bridges CR, Edwards FH, Peterson ED, Coombs LP. The effect of race on coronary bypass operative mortality. J Am Coll Cardiol. 2000;36:1870-6.

6. Becker ER, Rahimi A. Disparities in race/ethnicity and gender in in-hospital mortality rates for coronary artery bypass surgery patients. J Natl Med Assoc. 2006;98:1729-39.

7. Eagle KA, Guyton RA, Davidoff R, Edwards FH, Ewy GA, Gardner TJ, et al; American College of Cardiology; American Heart Association. ACC/AHA 2004 guideline update for coronary artery bypass graft surgery: a report of the American College of Cardiology/American Heart Association task force on practice guidelines (committee to update the 1999 guidelines for coronary artery bypass graft surgery). Circulation. 2004;110:e340-437.

8. Shahian DM, O'Brien SM, Filardo G, Ferraris VA, Haan CK, Rich JB, et al; Society of Thoracic Surgeons Quality Measurement Task Force. The Society of Thoracic Surgeons 2008 cardiac surgery risk models: part 1-coronary artery bypass grafting surgery. Ann Thorac Surg. 2009;88:S2-22.

9. Roques F, Nashef SA, Michel P, Gauducheau E, de Vincentiis C, Baudet E, et al. Risk factors and outcome in European cardiac surgery: analysis of the EuroSCORE multinational database of 19030 patients. Eur J Cardiothorac Surg. 1999; 15:816-22.

10. Stroup DF, Berlin JA, Morton SC, Olkin I, Williamson GD, Rennie D, et al. Metaanalysis of observational studies in epidemiology: a proposal for reporting. Metaanalysis of observational studies in epidemiology (MOOSE) group. JAMA. 2000; 283:2008-12.

11. Wells GA, Shea B, O'Connell D, Peterson J, Welch V, Tugwell P. The NewcastleOttawa Scale (NOS) for assessing the quality of nonrandomised studies in metaanalysis. Presented at: 3rd Symposium on Systematic Reviews: Beyond the Basics; July 3-5, 2000. Oxford, United Kingdom.

12. DerSimonian R, Laird N. Meta-analysis in clinical trials. Control Clin Trials. 1986;7:177-88.

13. Mantel N, Haenszel W. Statistical aspects of the analysis of data from retrospective studies of disease. J Natl Cancer Inst. 1959;22:719-48.

14. Hunter JE, Schmidt FL. Fixed effects vs random effects meta-analysis models: implications for cumulative research knowledge. Int J Sel Assess. 2000;8:275-92.
15. Higgins JP, Thompson SG. Quantifying heterogeneity in a meta-analysis. Stat Med. 2002;21:1539.

16. Efird JT, O’Neal WT, Griffin WF, Anderson EJ, Davies SW, Landrine H, et al. Increased coronary artery disease severity in black women undergoing coronary bypass surgery. Medicine (Baltimore). 2015;94:e552.

17. Pollock B, Hamman BL, Sass DM, Da graca B, Grayburn PA, Filardo G. Effect of gender and race on operative mortality after isolated coronary artery bypass grafting. Am J Cardiol. 2015;115:614-8.

18. Kaila KS, Norris CM, Graham MM, Ali I, Bainey KR. Long-term survival with revascularization in South Asians admitted with an acute coronary syndrome (from the Alberta provincial project for outcomes Assessment in coronary heart disease registry). Am J Cardiol. 2014;114:395-400.

19. Rangrass G, Ghaferi AA, Dimick JB. Explaining racial disparities in outcomes after cardiac surgery: the role of hospital quality. JAMA Surg. 2014;149:223-7.

20. Gasevic D, Khan NA, Qian H, Karim S, Simkus G, Quan H, et al. Outcomes following percutaneous coronary intervention and coronary artery bypass grafting surgery in Chinese, South Asian and White patients with acute myocardial infarction: administrative data analysis. BMC Cardiovasc Disord. 2013;13:121.

21. Kim DH, Daskalakis C, Lee AN, Adams S, Hohmann S, Silvestry SC, et al. Racial disparity in the relationship between hospital volume and mortality among patients undergoing coronary artery bypass grafting. Ann Surg. 2008;248:886-92.

22. Brister SJ, Hamdulay Z, Verma S, Maganti M, Buchanan MR. Ethnic diversity: South Asian ethnicity is associated with increased coronary artery bypass grafting mortality. J Thorac Cardiovasc Surg. 2007;133:150-4.

23. Konety SH, Vaughan Sarrazin MS, Rosenthal GE. Patient and hospital differences underlying racial variation in outcomes after coronary artery bypass graft surgery. Circulation. 2005;111:1210-6.

24. Maynard C, Ritchie JL. Racial differences in outcomes of veterans undergoing coronary artery bypass grafting. Am J Cardiol. 2001;88:893-5.A8.

25. Gray RJ, Nessim S, Khan SS, Denton T, Matloff JM. Adverse 5-year outcome after coronary artery bypass surgery in blacks. Arch Intern Med. 1996;156:769-73.

26. Trivedi AN, Sequist TD, Ayanian JZ. Impact of hospital volume on racial disparities in cardiovascular procedure mortality. J Am Coll Cardiol. 2006;47:417-24.

27. Michael Smith J, Soneson EA, Woods SE, Engel AM, Hiratzka LF. Coronary artery bypass graft surgery outcomes among African-Americans and Caucasian patients. Int J Surg. 2006;4:212-6.

28. Cooper WA, Thourani VH, Guyton RA, Kilgo P, Lattouf OM, Chen EP, et al. Racial disparity persists after on-pump and off-pump coronary artery bypass grafting. Circulation. 2009;120(11 suppl):S59-64.

29. O'Neal WT, Efird JT, Davies SW, O'Neal JB, Griffin WF, Ferquson TB, et al. Discharge $\beta$-blocker use and race after coronary artery bypass grafting. Front Public Health. 2014;2:94.

30. Mehta RH, Shahian DM, Sheng S, O'Brien SM, Edwards FH, Jacobs JP, et al; Society of Thoracic Surgery National Adult Cardiac Surgery Database; Duke Clinical Research Institute. Association of hospital and physician characteristics and care processes with racial disparities in procedural outcomes among contemporary patients undergoing coronary artery bypass grafting surgery. Circulation. 2016;133:124-30. 
31. Anderson JE, Li Z, Romano PS, Parker J, Chang DC. Should risk adjustment for surgical outcomes reporting include sociodemographic status? A study of coronary artery bypass grafting in California. J Am Coll Surg. 2016;223:221-30.

32. Keeling WB, Binongo J, Halkos ME, Leshnower BG, Nguyen DQ, Chen EP, et al. The racial paradox in multiarterial conduit utilization for coronary artery bypass grafting. Ann Thorac Surg. 2017;103:1214-21.

33. Chowdhury R, Davis WA, Chaudhary MA, Jiang W, Zogg CK, Schoenfeld AJ, et al. Race-based differences in duration of stay among universally insured coronary artery bypass graft patients in military versus civilian hospitals. Surgery. 2017;161:1090-9.

34. Andrews RM, Moy E. Racial differences in hospital mortality for medical and surgical admissions: variations by patient and hospital characteristics. Ethn Dis. 2015;25:90-7.

35. Lucas FL, Stukel TA, Morris AM, Siewers AE, Birkmeyer JD. Race and surgical mortality in the United States. Ann Surg. 2006;243:281-6.

36. Hadjinikolaou L, Klimatsidas M, Maria iacona G, Spyt T, Samani NJ. Short- and medium-term survival following coronary artery bypass surgery in British IndoAsian and white Caucasian individuals: impact of diabetes mellitus. Interact Cardiovasc Thorac Surg. 2010;10:389-93.
37. Goldsmith I, Lip GY, Tsang G, Patel RL. Comparison of primary coronary artery bypass surgery in a British Indo-Asian and white Caucasian population. Eur Heart J. 1999;20:1094-100.

38. Zindrou D, Bagger JP, Smith P, Taylor KM, Ratnatunga CP. Comparison of operative mortality after coronary artery bypass grafting in Indian subcontinent Asians versus Caucasians. Am J Cardiol. 2001;88:313-6.

39. Kovesdy CP, Norris KC, Boulware LE, Lu JL, Ma JZ, Streja E, et al. Association of race with mortality and cardiovascular events in a large cohort of US veterans. Circulation. 2015;132:1538-48

40. Bucholz EM, Ma S, Normand SL, Krumholz HM. Race, socioeconomic status, and life expectancy after acute myocardial infarction. Circulation. 2015;132:1338-46.

41. Valerio L, Peters RJ, Zwinderman AH, Pinto-Sietsma SJ. Association of family history with cardiovascular disease in hypertensive individuals in a multiethnic population. J Am Heart Assoc. 2016;5:e004260.

Key Words: coronary artery bypass grafting, outcomes, meta-analysis, ethnicity, mortality

Readers who found these articles interesting may also like to read the following papers found in recent and future issues of our sister publications, Seminars in Thoracic and Cardiovascular Surgery and Operative Techniques in Thoracic and Cardiovascular Surgery!

\section{Adult: Coronary}

CURRENT READINGS: Current Readings: Single vs Bilateral Internal Mammary Artery in Coronary Artery Bypass Grafting. Sary F. Aranki. Semin Thoracic Surg 2018: 398-405.

ORIGINAL SUBMISSION: Functional Evaluation of the Myocardial Ischemia After Coronary Artery Bypass Surgery Using Coronary Flow Velocity Reserve in Left Ventricular Hypertrophy. Kentaro Honda. Semin Thoracic Surg 2018: In press

Commentary: Big Hearts, Little Reserve: Coronary Flow Velocity Reserve After Bypass Grafting in Patients With Left Ventricular Hypertrophy. Juan A. Crestanello. Semin Thoracic Surg 2019: In press

ORIGINAL SUBMISSION: Functional Evaluation of the Myocardial Ischemia After Coronary Artery Bypass Surgery Using Coronary Flow Velocity Reserve in Left Ventricular Hypertrophy. Kentaro Honda. Semin Thoracic Surg 2018: In press

ORIGINAL SUBMISSION: The Prevalence and Distribution of Occlusive Lesions of the Cerebral Arteries in Patients Undergoing Coronary Artery Bypass Graft Surgery: Tomohiro Tsunekawa. Semin Thoracic Surg 2018: 413-420

ORIGINAL SUBMISSION: "Frozen Apex” Repair of a Dilated Cardiomyopathy. Masashi Komeda. Semin Thoracic Surg 2018: 406-411

Commentary: The Frozen Apex: A Useful Addition to the Surgeons Armamentarium? James Kirklin. Semin Thoracic Surg 2018: 412 
Unadjusted risk of mortality

Asiatic

White

Study or Subgroup

Events Total Events

Odds Ratio

IV, Random, 95\% CI

Odds Ratio

South Asian vs white

Brister 2007

Gasevic 2013

Goldsmith 1999

Hadjinikolaou 2010

$1163-5505028$

$2.31[1.47,3.64]$

$\begin{array}{rrrrr}29 & 1163 & 55 & 5028 & 8.8 \% \\ 3 & 137 & 62 & 1507 & 3.0 \%\end{array}$

$0.52[0.16,1.68]$

$13 \quad 194$

$7 \quad 274$

Kaila 2014

Zindrou 2001

252

1507

$3.0 \%$

$2.66[0.93,7.61]$

190
2623
$7.8 \%$

$2.43[1.05,5.62]$

$28 \quad 2623$

$0.68[0.23,2.05]$

$2.01[1.20,3.37]$

Total $(95 \% \mathrm{Cl})$

2456

1458

$3.3 \%$

$1.72[1.12,2.66]$

Total events

80

$11543 \quad 31.3 \%$

208

Heterogeneity: $\mathrm{Tau}^{2}=0.13 ; \mathrm{Chi}^{2}=9.49, \mathrm{df}=5(P=.09) ; \mathrm{I}^{2}=47 \%$

Test for overall effect: $Z=2.47(P=.01)$

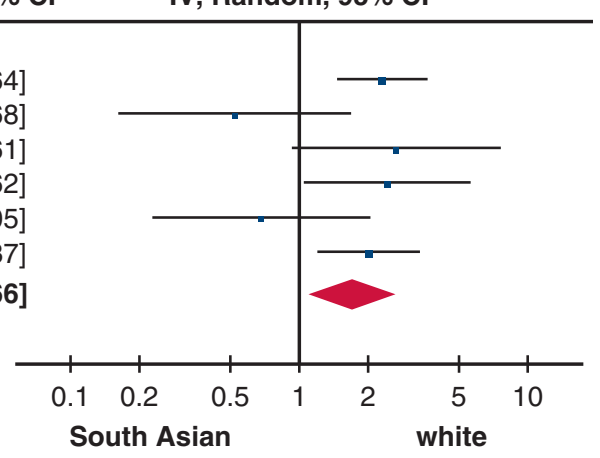

Adjusted risk of mortality

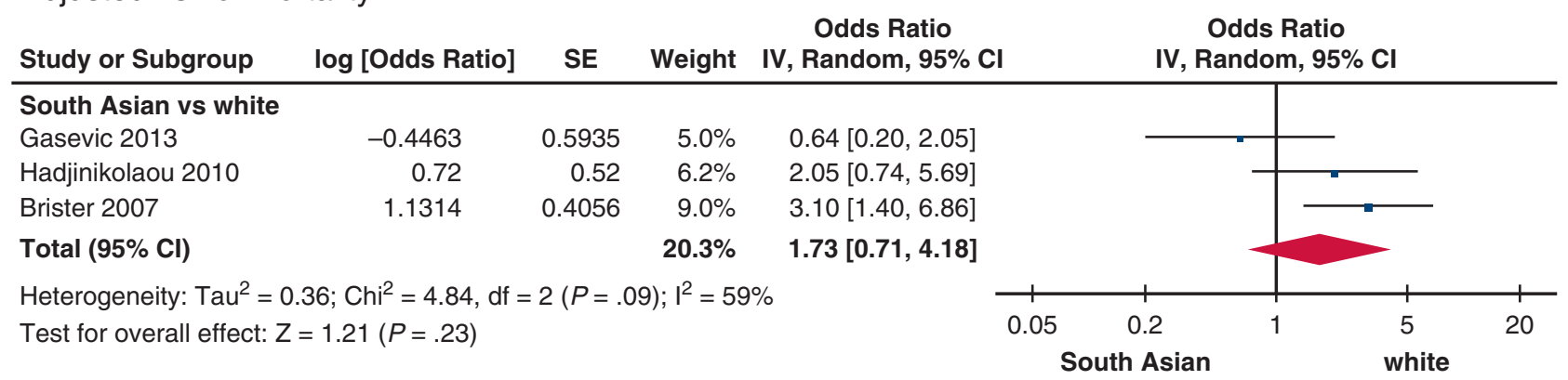

FIGURE E1. Meta-analytic unadjusted and adjusted risk of operative mortality in South Asian compared with white patients. $I V$, inverse variance; $C I$, confidence interval; $S E$, standard error. 


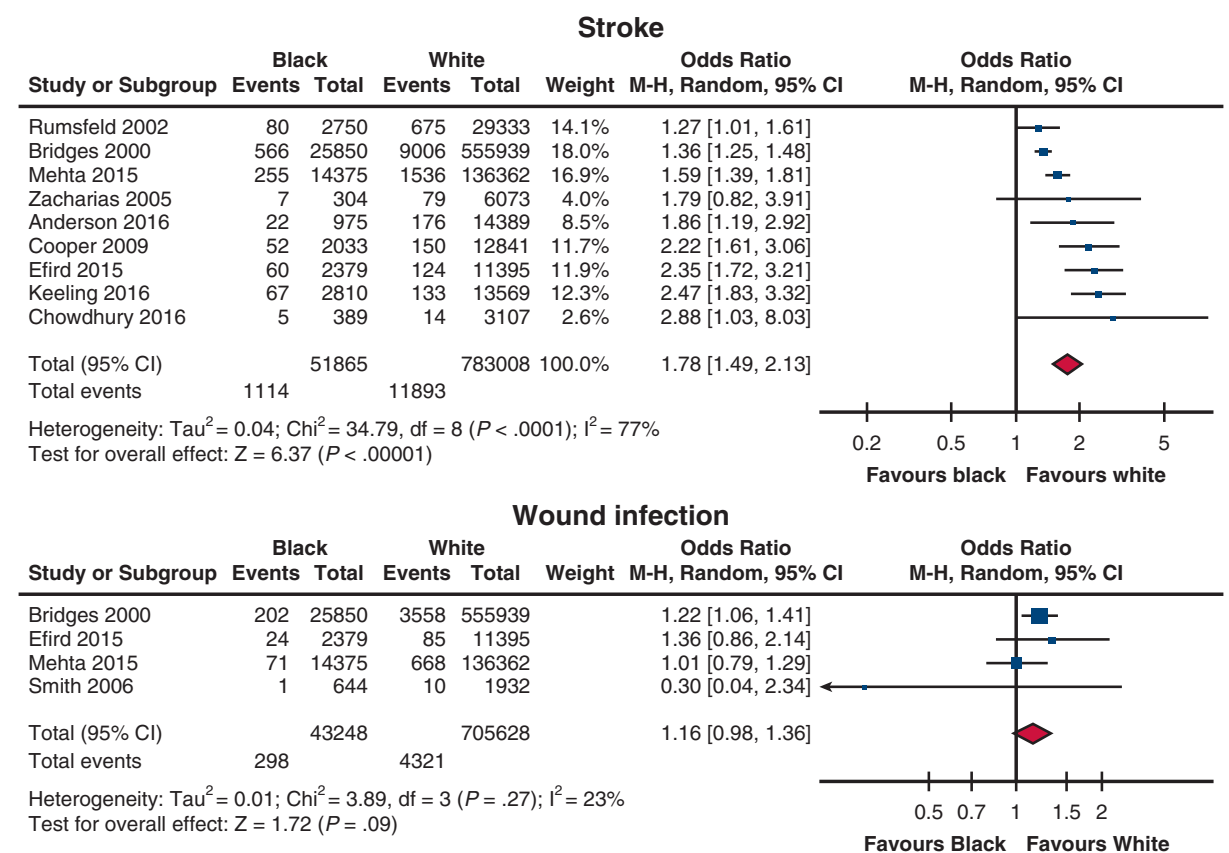

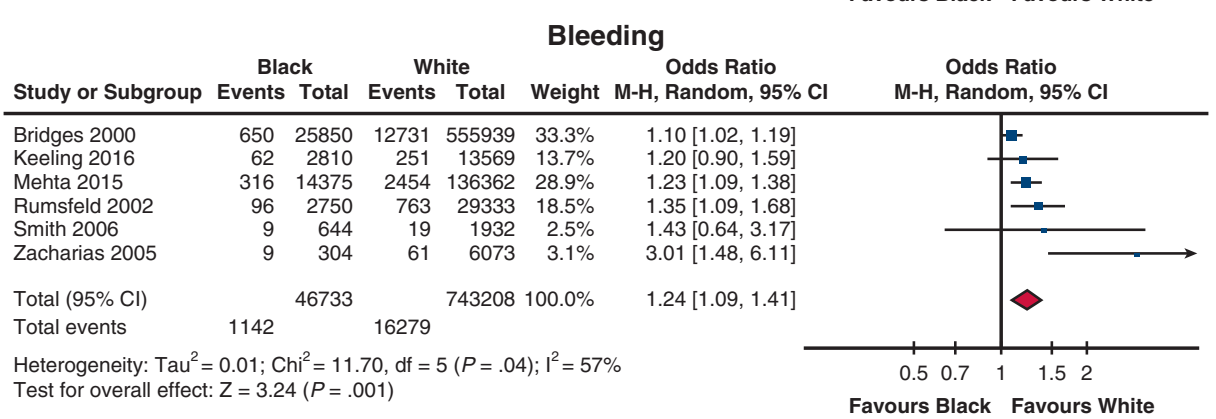

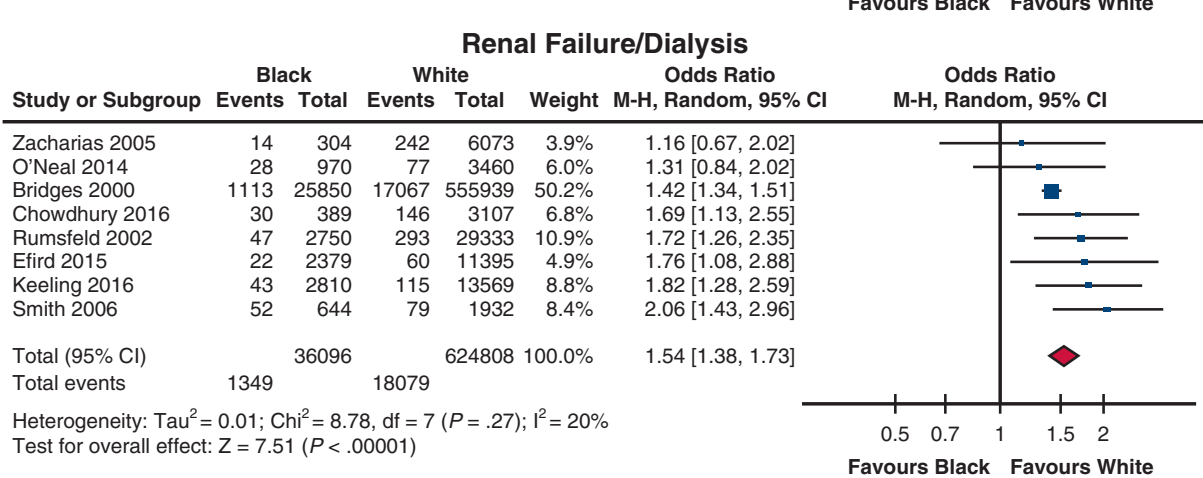

$$
\text { Test for overall effect: } Z=7.51(P<.00001)
$$

Prolonged ventilation/Tracheostomy

$$
\text { Black }
$$$$
\text { White }
$$$$
\text { Odds Ratio }
$$$$
\text { Odds Ratio }
$$

\begin{tabular}{|c|c|c|c|c|c|c|c|c|c|}
\hline O'Neal 2014 & 9 & 970 & 43 & 3460 & $4.4 \%$ & $0.74[0.36,1.53]$ & & & \\
\hline Mehta 2015 & 1585 & 14375 & 12933 & 136362 & $22.7 \%$ & $1.18[1.12,1.25]$ & & 를 & \\
\hline Zacharias 2005 & 24 & 304 & 394 & 6073 & $9.2 \%$ & $1.24[0.80,1.90]$ & & & \\
\hline Rumsfeld 2002 & 231 & 2750 & 1966 & 29333 & $19.9 \%$ & $1.28[1.11,1.47]$ & & $\rightarrow-$ & \\
\hline Bridges 2000 & 2053 & 25850 & 33634 & 555939 & $22.9 \%$ & $1.34[1.28,1.40]$ & & - & \\
\hline Keeling 2016 & 439 & 2810 & 1117 & 13569 & $20.9 \%$ & $2.06[1.83,2.32]$ & & & $\rightarrow-$ \\
\hline Total $(95 \% \mathrm{Cl})$ & & 47059 & & 744736 & $100.0 \%$ & $1.37[1.15,1.61]$ & & & \\
\hline Total events & 4341 & & 50087 & & & & & & \\
\hline \multicolumn{7}{|c|}{$\begin{array}{l}\text { Heterogeneity: } \mathrm{Tau}^{2}=0.03 ; \mathrm{Chi}^{2}=72.73, \mathrm{df}=5(P<.00001) ; \mathrm{I}^{2}=93 \% \\
\text { Test for overall effect: } Z=3.64(P=.0003)\end{array}$} & $0.5 \quad 0.7$ & 1.5 & 2 \\
\hline
\end{tabular}

Study or Subgroup Events Total Events Total Weight M-H, Random, $95 \% \mathrm{Cl} \quad \mathrm{M}-\mathrm{H}$, Random, $95 \% \mathrm{Cl}$

FIGURE E2. Meta-analytic estimates of unadjusted effect of black vs white race on postoperative complications. $M$ - $H$, Mantel-Haenszel; $C I$, confidence interval. 
TABLE E1. Severity of coronary artery disease in studies included in the meta-analysis

\begin{tabular}{|c|c|c|c|c|c|c|c|c|c|c|c|c|c|c|c|c|}
\hline \multirow{2}{*}{ Study } & \multicolumn{6}{|c|}{ EF, \% } & \multicolumn{5}{|c|}{ Triple-vessel disease, $\%$} & \multicolumn{5}{|c|}{ Left main coronary artery disease, $\%$} \\
\hline & $\begin{array}{c}\text { EF } \\
\text { expressed } \\
\text { as }\end{array}$ & White & Black & Asian & $\begin{array}{l}\text { South } \\
\text { Asian }\end{array}$ & Hispanic & White & Black & Asian & $\begin{array}{l}\text { South } \\
\text { Asian }\end{array}$ & Hispanic & White & Black & Asian & $\begin{array}{l}\text { South } \\
\text { Asian }\end{array}$ & Hispanic \\
\hline \multicolumn{17}{|l|}{ Anderson et al, ${ }^{31} 2016$} \\
\hline \multicolumn{17}{|l|}{ Andrews et al, ${ }^{34} 2015$} \\
\hline \multicolumn{17}{|l|}{$\begin{array}{l}\text { Becker and } \\
\text { Rahimi, }{ }^{6} 2006\end{array}$} \\
\hline Bridges et al, ${ }^{5} 2000$ & Mean (SD) & $51 \%(14)$ & $48 \%(14)$ & & & & $70 \%$ & $69 \%$ & & & & $20 \%$ & $19 \%$ & & & \\
\hline Brister et al, ${ }^{22} 2007$ & & & & & & & $76 \%$ & & & $79 \%$ & & $22 \%$ & & & $8 \%$ & \\
\hline \multicolumn{17}{|l|}{$\begin{array}{l}\text { Chowdhury } \\
\text { et al, }^{33} 2017\end{array}$} \\
\hline Cooper et al, ${ }^{28} 2009$ & Mean & $50 \%$ & $49 \%$ & & & & & & & & & $23 \%$ & $20 \%$ & & & \\
\hline Efird et al,$^{16} 2015$ & & & & & & & $66 \%$ & $68 \%$ & & & & $21 \%$ & $21 \%$ & & & \\
\hline Gasevic et al, ${ }^{20} 2013$ & & & & & & & $28 \%$ & & $28 \%$ & $27 \%$ & & $3 \%$ & & $5 \%$ & $3 \%$ & \\
\hline Goldsmith et al, ${ }^{37} 1999$ & Good EF & $52 \%$ & & & $56 \%$ & & $63 \%$ & & & $66 \%$ & & & & & & \\
\hline Gray et al, ${ }^{25} 1996$ & & & & & & & $64 \%$ & $68 \%$ & & & & $24 \%$ & $22 \%$ & & & \\
\hline $\begin{array}{l}\text { Hadjinikolaou } \\
\text { et al, }{ }^{36} 2010\end{array}$ & $\mathrm{EF} \geq 30 \%$ & $93 \%$ & & & $95 \%$ & & & & & & & & & & & \\
\hline Kaila et al, ${ }^{18} 2014$ & $\mathrm{EF}>35 \%$ & $72 \%$ & & & $68 \%$ & & & & & & & $7 \%$ & & & $6 \%$ & \\
\hline Keeling et al, ${ }^{32} 2017$ & Mean (SD) & $52 \%(12)$ & $50 \%(13)$ & & & & & & & & & & & & & \\
\hline \multicolumn{17}{|l|}{ Kim et al, ${ }^{21} 2008$} \\
\hline \multicolumn{17}{|l|}{ Konety et al, ${ }^{23} 2005$} \\
\hline \multicolumn{17}{|l|}{ Lucas et al,,$^{35} 2006$} \\
\hline \multicolumn{17}{|l|}{$\begin{array}{l}\text { Maynard and } \\
\text { Ritchie, }{ }^{24} 2001\end{array}$} \\
\hline Mehta et al, ${ }^{30} 2016$ & Median & $55 \%$ & $53 \%$ & & & & $95 \%$ & $94 \%$ & & & & $32 \%$ & $29 \%$ & & & \\
\hline $\mathrm{O}^{\prime}$ Neal et al, ${ }^{29} 2014$ & & & & & & & $67 \%$ & $68 \%$ & & & & $26 \%$ & $27 \%$ & & & \\
\hline Pollock et al, ${ }^{17} 2015$ & Mean (SD) & $49 \%(14)$ & $47 \%(16)$ & & & $47 \%(14)$ & & & & & & $29 \%$ & $28 \%$ & & & $29 \%$ \\
\hline \multicolumn{17}{|l|}{ Rangrass et al, ${ }^{19} 2014$} \\
\hline Rumsfeld et al, ${ }^{4} 2002$ & $\mathrm{EF}>35 \%$ & $89 \%$ & $87 \%$ & & & $88 \%$ & $72 \%$ & $73 \%$ & & & $76 \%$ & & & & & \\
\hline Smith et al, ${ }^{27} 2006$ & $\mathrm{EF}>40 \%$ & $78 \%$ & $75 \%$ & & & & & & & & & & & & & \\
\hline \multicolumn{17}{|l|}{ Trivedi et al, ${ }^{26} 2006$} \\
\hline Yeo et al, ${ }^{3} 2007$ & $\mathrm{EF}>30 \%$ & $92 \%$ & $89 \%$ & & & $89 \%$ & $77 \%$ & $77 \%$ & & & $78 \%$ & $24 \%$ & $23 \%$ & & & $23 \%$ \\
\hline Zacharias et al, ${ }^{2} 2005$ & Mean (SD) & $50 \%(11)$ & $49 \%(12)$ & & & & $72 \%$ & $73 \%$ & & & & $19 \%$ & $18 \%$ & & & \\
\hline Zindrou et al,,$^{38} 2001$ & $\mathrm{EF}>35 \%$ & $88 \%$ & & & $85 \%$ & & & & & & & $1 \%$ & & & $1 \%$ & \\
\hline
\end{tabular}

$E F$, Ejection fraction; $S D$, standard deviation. 
TABLE E2. Methods and variables used in adjusting for hospital mortality

\begin{tabular}{|c|c|c|c|}
\hline \multirow[b]{2}{*}{ Study } & \multirow[b]{2}{*}{ Adjustment methods } & \multicolumn{2}{|l|}{ Adjustment variables } \\
\hline & & Patient-level factors & Hospital-level factors \\
\hline Anderson et al, ${ }^{31} 2016$ & Logistic regression analysis & Age, age-sex interaction, sex & All patient-refined DRG \\
\hline Becker and Rahimi, ${ }^{6} 2006$ & Logistic regression analysis & $\begin{array}{l}\text { Admission type, sex, insurance status, procedure } \\
\text { characteristics, SES, smoking, year of procedure, } \\
\text { cardiomyopathy, COPD, CHF, CLD, CRF, CVD, } \\
\text { dysrhythmias, DM, HD, HTN, MI, obesity, previous } \\
\text { CABG, PVD, RF, unstable angina, valve disease }\end{array}$ & \\
\hline Brister et al, ${ }^{22} 2007$ & Logistic regression analysis & Age, EF, HTN, and unstable angina & \\
\hline Cooper et al, ${ }^{28} 2009$ & Logistic regression analysis & $\begin{array}{l}\text { Age, anticoagulants, beta blockers, BMI, BSA, diuretics, EF, } \\
\text { sex, height, IABP, immunosuppressive therapy, inotropes, } \\
\text { nitrates, last creatinine level, resuscitation, smoking, } \\
\text { status, weight, cardiogenic shock, COPD, CVA, CVD, } \\
\text { DM, HD, HF, HLD, HTN, left main disease, MI, number } \\
\text { of diseased vessels, PVD, RF }\end{array}$ & \\
\hline Gasevic et al, ${ }^{20} 2013$ & Logistic regression analysis & $\begin{array}{l}\text { Age, distance from nearest hospital, sex, SES, time from MI } \\
\text { to revascularization, arrhythmia, ARF, cancer, cardiogenic } \\
\text { shock, CHF, CRF, CVD, DM, severity of CAD }\end{array}$ & \\
\hline Hadjinikolaou et al, ${ }^{36} 2010$ & Logistic regression analysis & BMI, logistic EuroSCORE, DM, previous PCI & \\
\hline Keeling et al, ${ }^{32} 2017$ & Logistic regression analysis & $\begin{array}{l}\text { Age, creatinine level, EF, sex, height, IABP, } \\
\text { immunosuppressive therapy, resuscitation, single/ } \\
\text { multiple graft, status, weight, angina, arrhythmia, } \\
\text { cardiogenic shock, COPD, CVD, DM, endocarditis, HF, } \\
\text { HTN, MI, PAD, previous CV intervention, RF, valve } \\
\text { disease }\end{array}$ & \\
\hline Konety et $\mathrm{al}^{23} 2005$ & Logistic regression analysis & $\begin{array}{l}\text { Admission priority, age, sex, SES, year of surgery, DM, } \\
\text { CAD, CHF, COPD, CRF, CVD, HTN, PVD, previous } \\
\text { CABG or PCI }\end{array}$ & \\
\hline Lucas et al, ${ }^{35} 2006$ & Logistic regression analysis & $\begin{array}{l}\text { Age, sex, SES, urgency of admission, year of operation, } \\
\text { Charlson comorbidity score }\end{array}$ & $\begin{array}{l}\text { Hospital volume, } \\
\text { clustering by hospital }\end{array}$ \\
\hline Maynard and Ritchie, ${ }^{24} 2001$ & Logistic regression analysis & Age, IMA grafting, Deyo score, COPD, DM, HTN, MI & \\
\hline Mehta et al, ${ }^{30} 2016$ & Logistic regression analysis & Patient characteristics, surgeon, SES & Hospital identity \\
\hline Rangrass et al, ${ }^{19} 2014$ & Logistic regression analysis & $\begin{array}{l}\text { Age, emergency admission, sex, SES, Elixhauser } \\
\text { comorbidity index }\end{array}$ & Hospital quality \\
\hline Rumsfeld et al, ${ }^{4} 2002$ & Logistic regression analysis & $\begin{array}{l}\text { Age, BSA, EF, sex, IMA graft use, number of anastomoses, } \\
\text { preoperative ECG, preoperative diuretics and IV } \\
\text { nitroglycerin, preoperative IABP, priority of surgery, } \\
\text { serum creatinine, smoking, CAD, COPD, CVD, DM, } \\
\text { HTN, MI, NYHA class, preoperative mortality risk, } \\
\text { previous heart surgery, previous PCI, PVD, 3-vessel CAD }\end{array}$ & \\
\hline Trivedi et al, ${ }^{26} 2006$ & Logistic regression analysis & $\begin{array}{l}\text { Age, sex, urgency of admission, COPD, CHF, DM, } \\
\text { Elixhauser comorbidity index, PVD, HTN, MI }\end{array}$ & $\begin{array}{l}\text { Hospital volume and } \\
\text { clustering by hospital }\end{array}$ \\
\hline Zacharias et al, ${ }^{2} 2005$ & Logistic regression analysis & $\begin{array}{l}\text { Age, beta blockers, BSA, EF, sex, insurance status, } \\
\text { preoperative IABP, priority of procedure, procedure } \\
\text { characteristics, SES, smoking, arrhythmia, CHF, CVA, } \\
\text { CVD, COPD, DM, double vessel disease, HLD, HTN, left } \\
\text { main disease, MI, NYHA class, obesity, PVD, RF, triple- } \\
\text { vessel disease, unstable angina. }\end{array}$ & \\
\hline
\end{tabular}

$\overline{D R G}$, Diagnosis-Related Group; $S E S$, socioeconomic status; $C O P D$, chronic obstructive pulmonary disease; $C H F$, congestive heart failure; $C L D$, chronic liver disease; $C R F$, chronic renal failure; $C V D$, cerebrovascular disease; $D M$, diabetes mellitus; $H D$, hemodialysis; $H T N$, hypertension; $M I$, myocardial infarction; $C A B G$, coronary artery bypass graft; $P V D$, peripheral vascular disease; $R F$, renal failure; $E F$, ejection fraction; $B M I$, body mass index; $B S A$, body surface area; $I A B P$, intra-aortic balloon pump; $C V A$, cerebrovascular accident; $H F$, heart failure, $H L D$, hyperlipidemia; $A R F$, acute renal failure; $C A D$, coronary artery disease; $P A D$, peripheral arterial disease; $C V$, cardiovascular; $P C I$, percutaneous coronary intervention; IMA, internal mammary artery; ECG, electrocardiogram; $I V$, intravenous; NYHA, New York Heart Association. 